(C) O.O. Анісімов ${ }^{1}$

${ }^{1}$ Національний технічний університет «Дніпровська політехніка», Дніпро, Україна МЕТОДИКА ВИЗНАЧЕННЯ НАПРЯМКУ ПОГЛИБЛЕННЯ ДНА
КАР'СРУ

(C) O. Anisimov ${ }^{1}$

${ }^{1}$ Dnipro University of Technology, Dnipro, Ukraine

\title{
THE METHOD OF DETERMINING THE DIRECTION OF DEEPENING OF A PIT FLOOR
}

Мета. Створена методика визначення напрямку поглиблення дна глибокого кар'єру при розробці залізорудних родовищ і формуванні бортів глибоких кар'єрів крутонахиленими шарами призначена для глибоких крутоспадних родовищ.

Методика дослідження полягає у встановленні послідовності визначення куту і напрямку поглиблення дна кар'єру за запропонованою технологічною схемою. При відпрацюванні крутонахилених шарів поглиблення дна глибокого кар'єру досягається за рахунок правильного розміщення розкривної виробки (траншеї). Виділення на родовищі черг розробки дозволяє сформувати дно кар'єру з наступним посуванням фронту гірничих робіт з використання крутонахилених шарів для чого застосовано графоаналітичний метод з використанням геологічних розрізів крутоспадного родовища.

Результати дослідження. Створена методика що дозволяє визначити кути напрямку поглиблення дна кар'єру. Запропоновані нові аналітичні залежності, які дозволяють за двома суміжними геологічними розрізами визначити середній кут напрямку відпрацювання крутоспадаючого родовища. При поетапному формуванні кар'єру кут напрямку відпрацювання родовища в межах етапу запропоновано визначити як середнє значення кутів напрямку відпрацювання по горизонтах.

Наукова новизна. Встановлено аналітичні залежності для визначення куту і напрямку поглиблення дна кар'єру з урахуванням кутів укосів по висячому і лежачому борту кар'єру, що дозволяє визначати найбільш перспективні напрямки поглиблення (кути) за існуючими найближчими геологічними розрізами.

Практичне значення. Встановлена можливість графоаналітичним методом визначати доцільний напрямок поглиблення дна кар'єру як на окремому горизонті, так і у межах блоку при етапному формуванні робочої зони. Результати досліджень дозволили виконати аналіз розрізів в умовах кар'єру Полтавського ГЗК і підготовити дані по встановленню показників поглиблення дна кар'єру при етапному відпрацюванні крутонахиленими шарами.

Ключові слова: кут напрямку поглиблення дна кар'єру, крутонахилені шари, технологічні схеми відкритої розробки родовищ.

Вступ. Відомо, що необхідність зменшення об'ємів виймання порід розкриву на певному етапі розробки кар'єру привела до реалізації схем з формуванням тимчасово неробочих ділянок бортів і навіть із консервацією окремих бортів (рис. 1). Така консервація здійснювалася, як правило, з боку висячого боку родовища (рис. 1, б) і вимагала відпрацювання певної частини розкриву у більш піз- 
ній період. Можливі напрямки відпрацювання кар'єрного поля в глибину представлені на рис. 1. Наявні схеми розробки родовища мають кути укосів робочих бортів у межах до $24^{\circ}$ (рис. 1 , а).

a

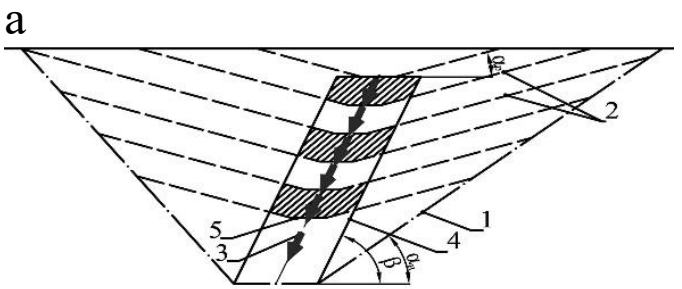

B
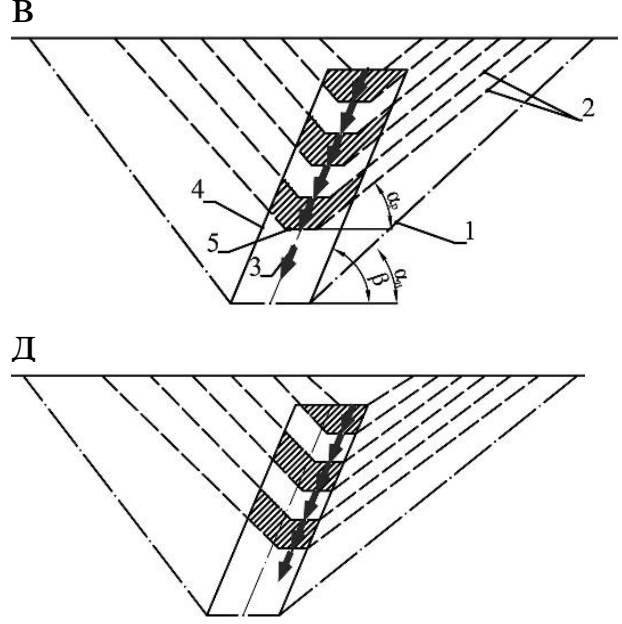

Ж

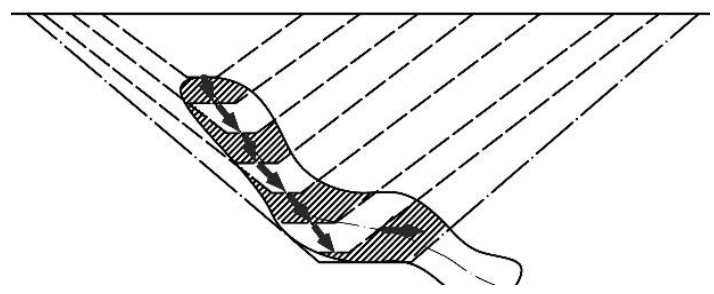

И

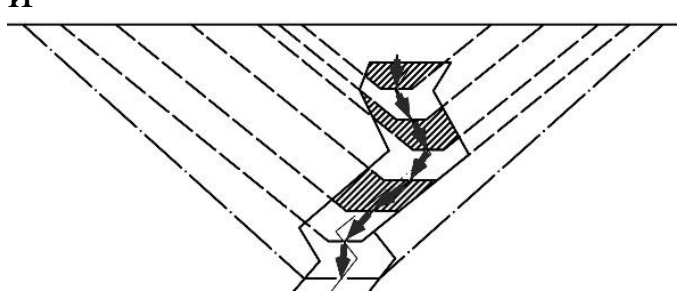

6

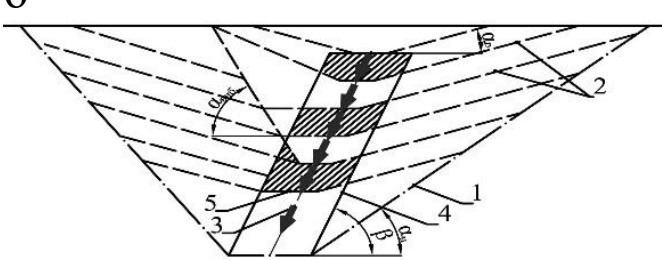

$\Gamma$

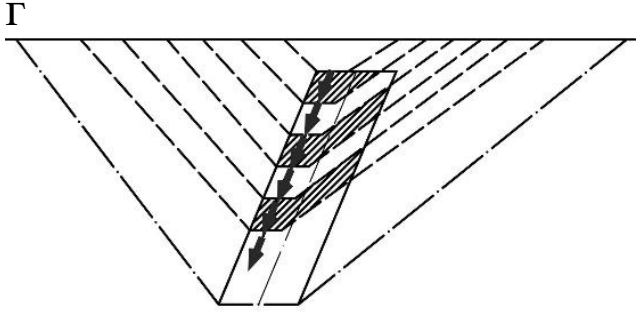

$\mathrm{e}$

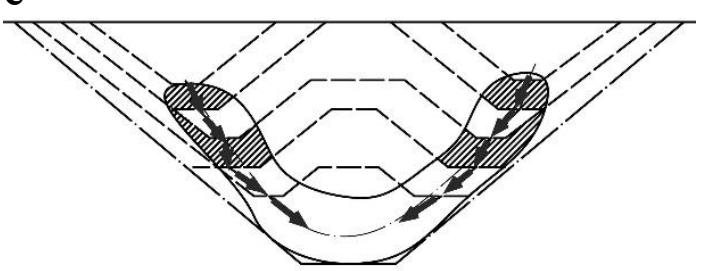

3

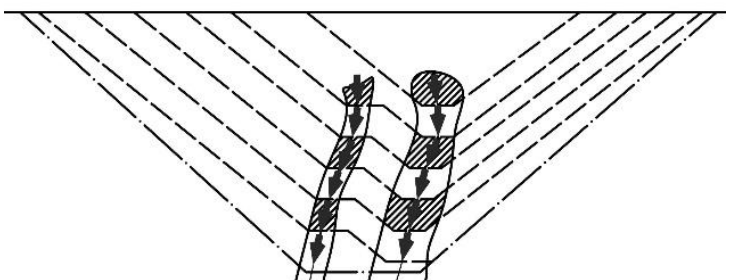

К

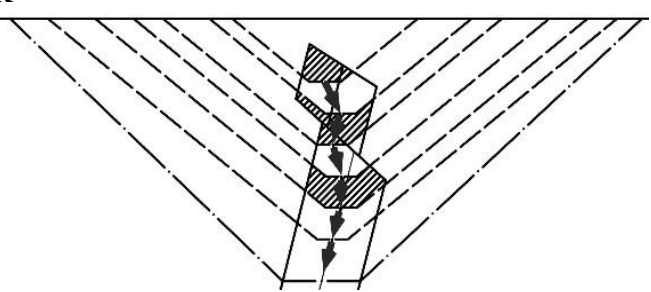

Л

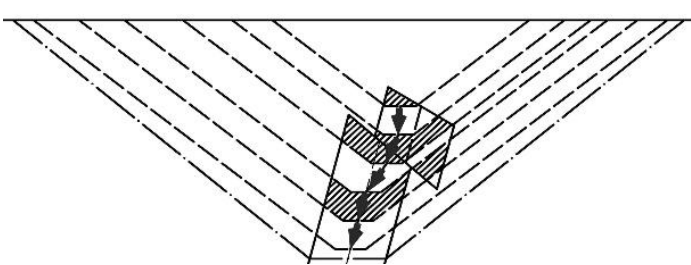

Рис. 1. Напрямок відпрацювання кар'єрного поля в поперечному розрізі з формуванням: $а$ - нормативних укосів фронтальних бортів; $\sigma$ - розробка із залишенням тимчасово неробочих бортів; в-л - відпрацювання родовищ крутонахиленими шарами: 1 - проектні контури кар'єру; 2 - робочі контури кар'єру на певних етапах; 3 - напрямок розвитку фронту гірничих робіт; 4 - контури родовища; 5 - положення дна кар'єру на різних етапах розвитку гірничих робіт 
Проблеми розробки крутоспадних родовищ з використанням крутонахилених шарів з формуванням виробленого простору і визначенню послідовності і напрямку розробки залізорудних родовищ розглянуті в роботах [1-7].

Формування цілей статті. Розробка крутонахиленими шарами глибоких кар'єрів супроводжується значними обсягами виймання порід розкриву. Послідовність формування крутнахилених шарів призводить до необхідності підтримування ділянок виймання в нижній частині кар'єрного поля для забезпечення розкритих запасів корисної копалини.

На початковому етапі експлуатації крутоспадаючого родовища з урахуванням наявної механізації гірничих робіт визначають параметри уступу. Як відомо, розробка нового горизонту починається із проведення капітальної і розрізної траншеї на висоту уступу. Для обрання напрямку розробки кар'єрного поля в глибину необхідно орієнтуватися на середину поздовжнього покладу на визначеному горизонті. У більшості випадків розрізну траншею орієнтують у плані по простяганню покладу. При відпрацюванні крутоспадаючих покладів бажано орієнтувати і розташовувати середину траншеї уздовж вісі простягання родовища. Таке положення дає можливість рівномірно виконувати розкривні робити і вчасно здійснювати підготовку покладу корисної копалини до виймання.

При розгляді родовища як об'ємного об'єкта, на кожному етапі його відпрацювання слід визначити доцільний напрямок розвитку гірничих робіт у глибину. Для цього можливо скористатися поздовжніми і поперечними розрізами родовища. У випадку, якщо родовище має неправильну форму або у ньому є геологічні порушення, це дозволить уникнути помилки і визначити напрямок розвитку гірничих робіт по всьому розкритому блоку на горизонті. Визначення кута напрямку розвитку кожного окремого етапу по глибині дозволить визначити у цілому об’єми виймання порід розкриву у межах кар'єрного поля з боку висячого і лежачого боків родовища.

Виклад основного матеріалу. Методика визначення доцільного кута напрямку розвитку гірничих робіт за глибиною полягає в наступному:

- здійснюється аналіз поперечних і поздовжніх розрізів родовища до кінцевої глибини його розробки;

- визначається положення гірничих робіт при черговому розкритті кожного горизонту з урахуванням висоти уступу;

- знаходиться середня лінія на нижній площадці горизонту, до якої прив'язують параметри траншеї (кути закладення і укоси, ширину дна траншеї). Середньою точкою дна траншеї в поперечному розрізі $\epsilon$ точка, відносно якої встановлюється напрямок розвитку гірничих робіт за глибиною наступного горизонту;

- визначаються кути падіння покладу з боку висячого і лежачого боків родовища на нижньому горизонті, знаходять їх середні значення по двох найближчих розрізах;

- 3 урахуванням етапності розвитку гірничих робіт виникає необхідність у визначенні напрямку розвитку гірничих робіт із глибиною. У цьому випадку слід враховувати всі середні кути напрямку розвитку гірничих робіт у межах кожного 
етапу по глибині, тому що його зміна веде до зменшення або збільшення кількості крутонахилених шарів;

- для обгрунтування напрямку поглиблення кар'єра в межах етапу на об'ємній фігурі визначаються на найближчих розрізах значення кутів укосу і знаходиться їхня середня величина.

Графічно дана методика наведена на рис. 2, 3. Так, на рис. 2 зображені два найближчих геологічних розрізи родовища. Якщо при відпрацюванні родовища його поділяють на окремі ділянки, то визначення напрямку поглиблення на них провадиться за середнім значенням кута падіння покладу по кожному етапу відпрацювання. Етапи формують за глибиною для даних розрізів з однаковими позначками поверхні. Якщо родовище має ідеальну форму і постійний кут падіння, то для визначення напрямку його поглиблення досить знати кут падіння покладу.

У випадку, якщо родовище має горизонтальну потужність по падінню і кут падіння покладу, що змінюються з боку висячого і лежачого боків, то необхідно графічно або аналітично визначити напрямок поглиблення. При цьому напрямок поглиблення пропонується визначати по розрізах у межах блоків, що утворюють ці розрізи.

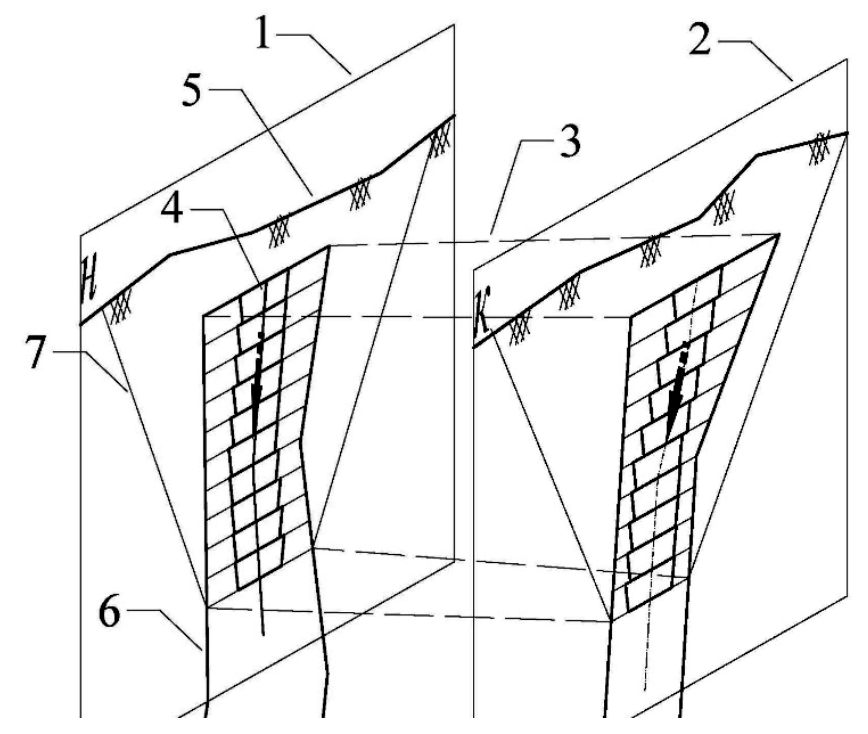

Рис. 2. Схема для розрахунку середнього кута напрямку відпрацювання крутоспадаючого родовища: 1 і 2 - відповідно найближчі розрізи $н$ і $\kappa$; 3 - проекція блоків, що враховує відстань між розрізами; 4 - положення дна траншеї при відпрацюванні крутонахиленими шарами; 5 - поверхня землі; 6 - зображення покладу на розрізі; 7 - границі кар'єрного поля на розрізі

На рис. 3, а показано, як змінюються площі крутонахилених шарів при відпрацюванні етапів. Зміна кута падіння покладу веде до зміни площі, що формується крутонахиленими шарами, і відповідно, змінюються об'єми виймання порід розкриву у межах етапу. Так, виходячи із зображення, на початковому етапі видобування корисної копалини для подальшого розвитку гірничих робіт слід виймати породи розкриву зі сторони висячого боку $V_{n 1}$. У той же час роботи зі 
сторони лежачого боку в цей момент відбуватися не будуть. I тільки на третьому і четвертому етапі поглиблення залучаються до розробки породи $V_{л 3}, V_{л 4}$.

a

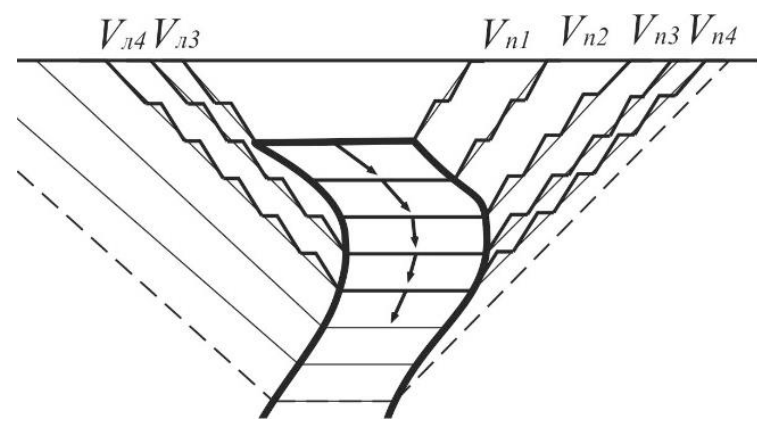

6

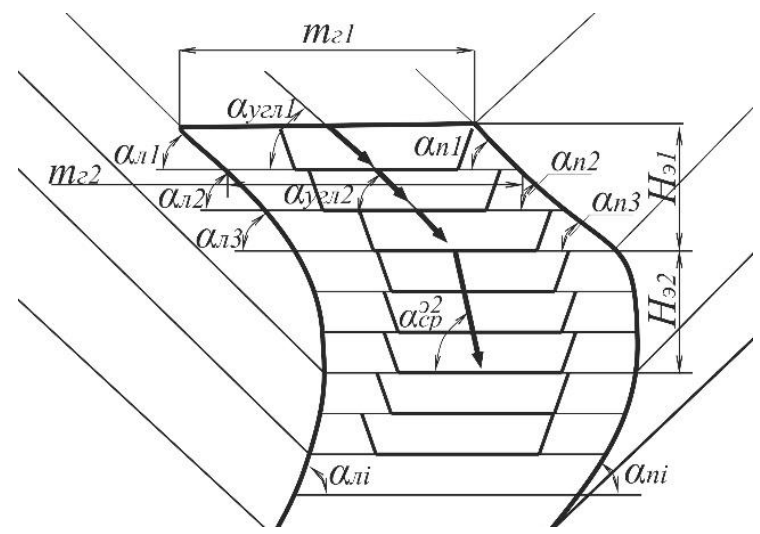

Рис. 3. Схеми поглиблення дна кар'єру при розробці пластового родовища:

a - загальна схема, що роз'яснює розподіл об'ємів порід розкриву при відпрацюванні крутонахиленими шарами; б - параметри покладу, що дозволяють визначити кут напрямку поглиблення кар'єрного поля при відпрацюванні його крутонахиленими шарами

Аналітичні залежності визначення напрямку поглиблення кар'єру отримані на основі аналізу схеми, що представлена на рис. 3, б. Порядок їх наступний:

1. Визначається початкове положення точки поглиблення на першому розрізі (маркіруємо його «н») і на другому, найближчому до нього (маркіруємо його «К»).

$$
\begin{aligned}
& l_{c p 1}^{H}=\frac{m_{21}^{H}}{2} ; l_{c p 2}^{H}=\frac{m_{21}^{H}}{2} ; \ldots l_{c p i}^{H}=\frac{m_{2 i}^{H}}{2}, \\
& l_{c p 1}^{\kappa}=\frac{m_{21}^{\kappa}}{2} ; l_{c p 2}^{\kappa}=\frac{m_{\imath 2}^{\kappa}}{2} ; \ldots l_{c p i}^{\kappa}=\frac{m_{2 i}^{\kappa}}{2},
\end{aligned}
$$

де $l_{c p i}^{\mu}, l_{c p i}^{\kappa}$ - положення середньої точки відносно потужності пласту на певному $i-м$ горизонті, відповідно для першого і другого розрізів, м; $m_{\imath i}^{H}, m_{\imath i}^{\kappa}-$ горизонтальна потужність рудного пласта на $i$-му горизонті, відповідно для першого і другого розрізів, м.

2. Визначається кут напрямку поглиблення горизонту на двох суміжних розрізах, як середнє значення кутів падіння покладу зі сторін висячого і лежачого боків:

$$
\alpha_{y z \lambda . i}^{H}=\frac{\alpha_{n i}^{H}+\alpha_{n i}^{H}}{2} ; \quad \alpha_{y z \lambda . i}^{\kappa}=\frac{\alpha_{n i}^{\kappa}+\alpha_{n i}^{\kappa}}{2},
$$

де $\alpha_{n i}^{n}, \alpha_{n i}^{H}$ - кут падіння родовища від правої і лівої границі на першому розрізі, град.; $\alpha_{л i}^{\kappa}, \alpha_{n i}^{\kappa}$ - кут падіння родовища від правої і лівої границі на другому розрізі, град. 
3. При поетапному формуванні кар'єру кут напрямку відпрацювання родовища в межах етапу можна визначити як середнє значення кутів напрямку відпрацювання по горизонтах (градусів)

$$
\alpha_{c p . j}^{H . \Im}=\frac{\alpha_{y 2 n 1}^{H}+\alpha_{y z л 2}^{H}+\ldots+\alpha_{y 2 n . i}^{H}}{j} ; \alpha_{c p . j}^{\kappa . \jmath}=\frac{\alpha_{y 2 n 1}^{\kappa}+\alpha_{y z n 2}^{\kappa}+\ldots+\alpha_{y 2 n . i}^{\kappa}}{j},
$$

де $j$ - кількість горизонтів в етапі, од.

4. Визначення кута напрямку поглиблення по блоку в межах етапу. По суті цей кут з'являється у середній частині об'ємного блоку етапу відпрацювання (рис. 4) і визначається за формулою:

$$
\alpha_{c p . j}^{\sigma . \jmath}=\frac{\alpha_{c p . j}^{\mu . \Im}+\alpha_{c p . j}^{\kappa . \ni}}{2}
$$

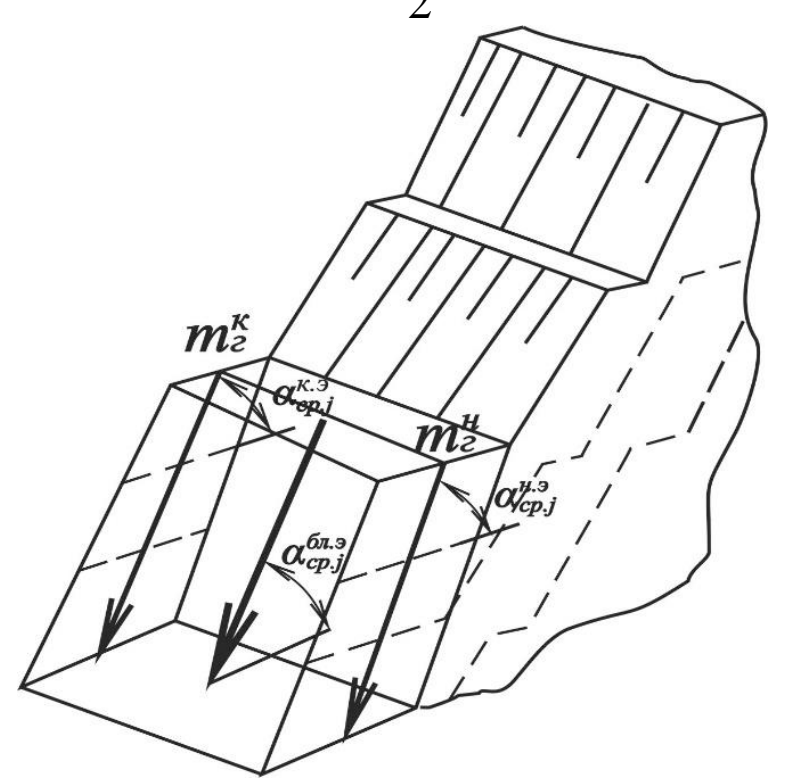

Рис. 4. Схема до визначення напрямку розвитку поглиблення кар'єру в блоці

Відпрацювання крутонахиленими шарами може провадитися 3 розміщенням розрізної траншеї по центральній лінії простягання родовища (див. рис. 1, в), а також ближче до висячого або лежачого його боку (див. рис. 1, г, д). Мульдоподібні родовища, як правило, відпрацьовуються з поглибленням по одному або обом крилах (рис. 1, е).

Як видно з рис. 1 (ж) до певного моменту поглиблення гірничих робіт здійснюється по центру покладу. Надалі крутонахилений поклад змінив положення на горизонтальне залягання. У цьому випадку, відпрацювання порід розкриву також слід провадити крутонахиленими виймальними шарами, однак напрямок їх посування у видобувній зоні буде здійснюватися в межах кар'єру практично горизонтально.

При наявності в межах кар'єрного поля декількох крутоспадаючих пластів корисної копалини можливе формування низки зон, що складаються із крутонахилених шарів. Як правило, основний напрямок їх поглиблення визначають за сукупністю потужностей родовища (якщо два або більше покладів розташовані поруч) або ж обирається пласт з найбільшими потужністю і вмістом корисного 
компоненту. На рис. 1 (з) показаний варіант відпрацювання родовища 3 двома пластами, горизонтальна потужність яких відрізняється один від одного.

Ламана форма крутоспадаючих родовищ зустрічається досить рідко i, як правило, така конфігурація пов'язана зі зсувом геологічних покладів у плані та в глибину. Неправильна форма пластового родовища, як показано на рис. 1 (и), приводить до необхідності поглиблення видобувних робіт за напрямком його падіння. При такій формі родовища крутонахилені виймальні шари по породах розкриву будуть відпрацьовуватися нерівномірно. Поступово будуть залучатися до розробки породи розкриву то правого, то лівого боку родовища.

Розглянуті також варіанти розвитку гірничих робіт на родовищах із вскиданням (рис. 1, к) або скиданням (рис. 1, л) рудного тіла при відповідних геологічних порушеннях. На початковому етапі розвитку гірничих робіт у таких умовах поглиблення дна кар'єру розглядається по найближчому положенню покладу до поверхні. Надалі, розвиток гірничих робіт на глибину відбувається по покладу з урахуванням його конфігурації, за тих умов, які були описані вище. При наявності подібних порушень, гірничі роботи з розробки порід розкриву крутонахиленими шарами також перерозподіляються на етапі переходу від одного положення покладу до іншого.

Важливе значення має напрям поглиблення дна кар'єру при етапному відпрацюванні крутонахиленими шарами. У якості прикладу для умов Полтавського ГЗК були визначені кути падіння залізорудного родовища по висячому і лежачому бокам (рис. 5).

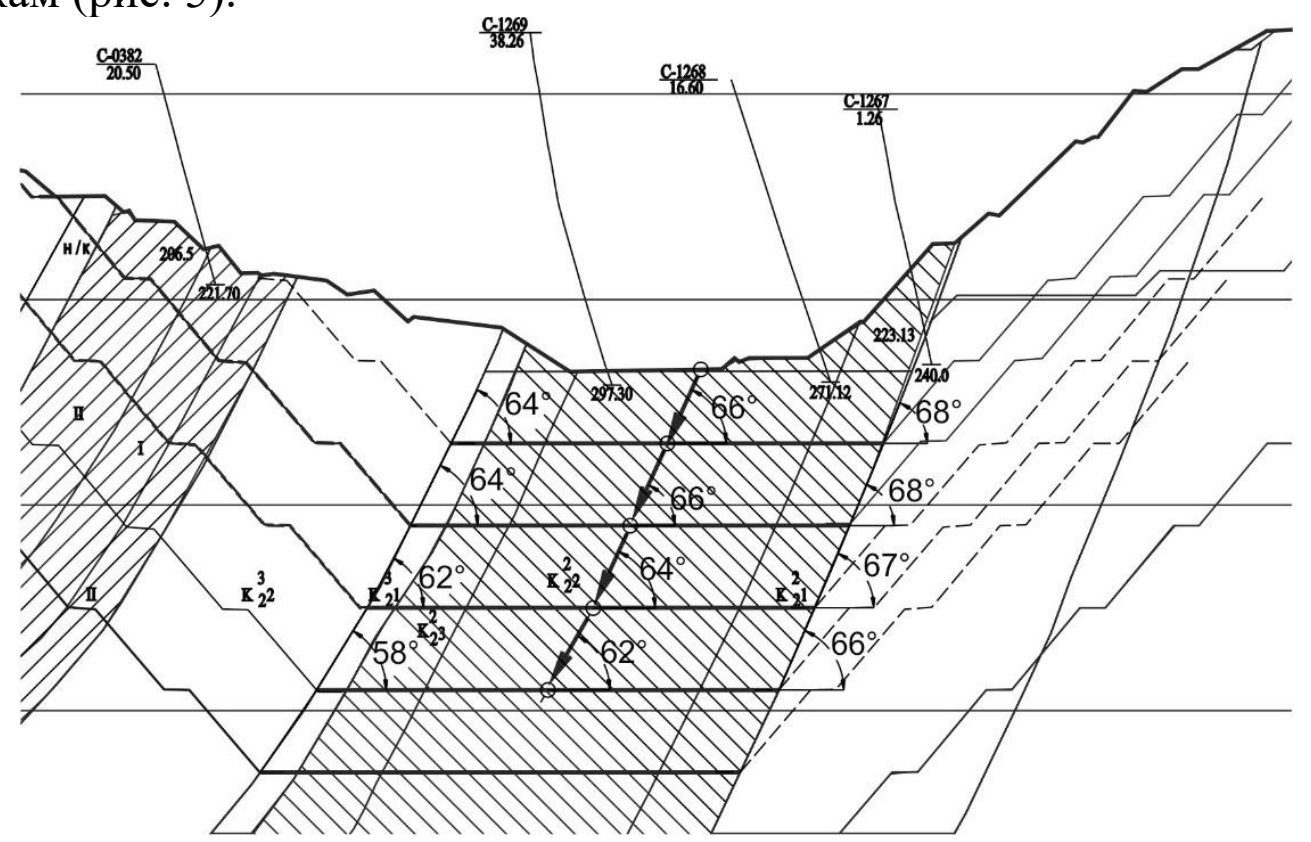

Рис. 5. Схема до визначення напрямку поглиблення дна на ГорішнєПлавнинському родовищі в кар'єрі Полтавського ГЗК

На підставі графічних побудов (рис. 5) підготовлені дані (табл. 1) по встановленню показників поглиблення дна кар'єру при етапному відпрацюванні крутонахиленими шарами. Встановлено, що кут поглиблення на кожному етапі змінюється від 66 до 62 градусів. 
Таблиця 1

Показники напрямку поглиблення Горішнє-Плавнинського родовища Полтавського ГЗКа

\begin{tabular}{|c|c|c|c|c|}
\hline Горизонт & $\begin{array}{c}\text { Кут залягання } \\
\text { шару з боку } \\
\text { висячого } \\
\text { борта, град }\end{array}$ & $\begin{array}{c}\text { Кут залягання } \\
\text { шару з боку } \\
\text { лежачого } \\
\text { борта, град. }\end{array}$ & $\begin{array}{c}\text { Кут } \\
\text { поглиблення } \\
\text { етапу, град }\end{array}$ & Потужність, м \\
\hline-270 & 64 & 68 & 66 & 210 \\
\hline-310 & 64 & 68 & 66 & 213 \\
\hline-350 & 62 & 67 & 64 & 217 \\
\hline-390 & 58 & 66 & 62 & 225 \\
\hline
\end{tabular}

Висновки. Встановлена можливість графоаналітичним методом визначати доцільний напрямок поглиблення дна кар'єру як на окремому горизонті, так і у межах блоку при етапному формуванні робочої зони. Напрямок розвитку робіт за глибиною визначається кутом падіння родовища, що впливає на об'єми виймання порід розкриву, а також на кількість і ширину робочих площадок у крутонахиленому шарі. Напрямок відпрацювання крутонахилених шарів по породам розкриву визначається виходячи з усереднення кутів формування бортів і етапів кар'єру, що забезпечують стійкий стан масиву при їх відпрацюванні.

\section{Перелік посилань}

1. Anisimov, O.O. (2018). Research on parameters of the working area on an internal dump for developing open pits. Scientific bulletin of National Mining University. (1). 11-17. https://doi.org/10.29202/nvngu/2018-1/17

2. Анісімов О.О. (2018) Спосіб відкритої розробки крутоспадних родовищ корисних копалин (Patent No. 117835).

3. Анисимов, О.А. (2015). Технологии строительства и разработки глубоких карьеров: монография. Национальный горный университет.

4. Symonenko, V. Cherniaiev, O., Hrytsenko, L., (2016). Organization of non-metallic deposits development by steep excavation layers. Mining of Mineral Deposits, 10 (4), 68-73. https://doi.org/10.15407/mining10.04.068

5. Симоненко, В.И., Черняев, А.В. (2006). К установлению зависимости между параметрами системы разработки при отработке нерудных месторождений с внутренним отвалообразованием. Геотехническая механика: Межвед. сб. науч. тр. Институт геотехнической механики им. М.С. Полякова, (62), 93-97.

6. Молдабаев, С.К., Анисимов, О.А. (2018). Перспективные схемы производства эксплуатационных и горно-подготовительных работ в глубоких рудных карьерах. Горный журнал Казахстана, (10), 7-11.

7. Анисимов, О.А. (2018). Формування бортів глибокого кар'єру крутими шарами. Збірник наукових пращь НГУ, (55), 8-17. http://nbuv.gov.ua/UJRN/znpngu_2018_55_3

\section{АННОТАЦИЯ}

Цель. Созданая методика определения направления углубления дна глубокого карьера при разработке железорудных месторождений и формировании бортов глубоких карьеров крутонаклонными слоями предназначена для глубоких крутопадающих месторождений. 
Методика исследования заключается в установлении последовательности определения угла и направления углубления дна карьера по предложенной технологической схеме. При отработке крутонаклонных слоев углубление дна глубокого карьера достигается за счет правильного размещения вскрывающей выработки (траншеи). Выделение на месторождении очередей разработки позволяет сформировать дно карьера с последующим подвиганием фронта горных работ при использовании крутонаклонных слоев для чего применен графоаналитический метод с использованием геологических разрезов крутопадающего месторождения.

Результаты исследования. Созданная методика позволяет определить углы направления углубления дна карьера. Предложены новые аналитические зависимости, позволяющие по двум смежным геологическим разрезам определить средний угол направления отработки крутопадающего месторождения. При поэтапном формировании карьера угол направления отработки месторождения в пределах этапа предложено определять как среднее значение углов направления отработки по горизонтам.

Научная новизна. Установлено аналитические зависимости для определения угла и направления углубления дна карьера с учетом углов откосов по висячему и лежачему бортах карьера, что позволяет определять наиболее перспективные направления углубления (углы) по существующим ближайшим геологическим разрезам.

Практическое значение. Установлена возможность графоаналитическим методом определять целесообразное направление углубления дна карьера как на отдельном горизонте, так и в пределах блока при этапном формировании рабочей зоны. Результаты исследований позволили выполнить анализ разрезов в условиях карьера Полтавского ГОКа и подготовить данные по установлению показателей углубления дна карьера при этапной отработке крутонаклонными слоями.

Ключевые слова: угол направления углубления дна карьера, крутонаклонные слои, технологические схемы открытой разработки месторождений.

\begin{abstract}
Purpose. The created method of determining the direction of deepening of a pit floor at development of iron ore deposits and formation of borders of deep pits by steeply inclined layers is intended for deep steep formation.

The research of the methodology is to establish the sequence of determining the angle and direction of deepening of the pit floor according to the proposed technological scheme. At working off of steeply inclined layers the deepening of a pit floor of a deep open pit is got at the expense of correct placement of explosive trench. The allocation of queues of development at the field allows to form the pit floor of the open pit with the subsequent movement of the mining front using steeply inclined layers. The graphoanalytical method using geological sections of the steep formation is used.
\end{abstract}

Findings. The created technique allows to determine the angles of the direction of deepening of the pit floor of the open pit. New analytical dependences are proposed, which allow to determine the average angle of the direction of development of the steep formation. With phased formation of the pit, the angle of the direction of development of the field within the stage is proposed as the average value of the angles of the direction of development on the horizons.

The originality. Analytical dependences have been established to determine the angle and the direction of deepening of the pit floor, taking into account the angles of slopes on the hanging and laying 
borders of the pit, which allows to determine the most promising directions of deepening (angles) on the existing nearest geological sections.

Practical implications. The graph-analytical method gives a possibility to determine the appropriate direction of deepening the pit floor of the open pit on a separate horizon and within the block during the stage formation of the working zone. The results of the research allowed to perform the analysis of sections in the conditions of the open pit of Poltava Mining and to prepare data on the establishment of indicators of deepening of the pit floor during staged development by steeply inclined layers.

Keywords: angle of the direction of deepening of a pit floor, steeply inclined layers, technological schemes of open development of deposits. 